\title{
Prince Arthur and Hercules Gallicus
}

\section{Abishek Sarkar}

Christophe Hausermann (ed.)

\section{OpenEdition}

\section{Journals}

Electronic version

URL: http://journals.openedition.org/shakespeare/2816

DOI: 10.4000/shakespeare.2816

ISSN: 2271-6424

\section{Publisher}

Société Française Shakespeare

Printed version

Date of publication: 1 May 2014

Number of pages: $73-87$

\section{Electronic reference}

Abishek Sarkar, "Prince Arthur and Hercules Gallicus », Actes des congrès de la Société française

Shakespeare [Online], 31 | 2014, Online since 01 May 2014, connection on 20 April 2019. URL : http:// journals.openedition.org/shakespeare/2816 ; DOI : 10.4000/shakespeare.2816 


\title{
Prince Arthur and Hercules Gallicus
}

\author{
Abishek SARKAR
}

\begin{abstract}
In Shakespeare's King John, the child Arthur uses his tongue to frustrate an attempt to blind him. As regards the remarkable success of his eloquence, Arthur may be seen as embodying a variation on the figure of Hercules Gallicus. The alleged portrait of Hercules celebrates his eloquence by showing him "with a long chayne tyed by one end at his tong, by the other end at the peoples eares, who stood a farre of that chayne fastned to his tong" (George Puttenham, The Arte of English Poesie). Arthur similarly captivates and subdues his adult adversary by his eloquence, although he lacks Hercules' age and stature. This obvious difference would serve to render Arthur's triumph more spectacular and theatrically compelling. One may ask, does the ascription of heavily rhetorical speeches to Arthur associate him inescapably with deceit and compromise his childlike-ness? Or else, is such obvious stylization meant to be appreciated as a stand-alone aesthetic stimulus, free from contingencies of narrative and vraisemblance? Even after factoring in the thick rhetorical apparatus of the play it may be possible to show, my article argues, that Arthur is an embattled child who uses rhetoric (and deceit) to cope with adult
\end{abstract} intentions.

Dans King John de Shakespeare, le jeune Arthur fait usage de sa verve afin de convaincre ses bourreaux de ne pas le rendre aveugle. Son talent d'éloquence n'est pas sans évoquer l'Hercule gaulois, figure mythique représentée dans un portrait "with a long chayne tyed by one end at his tong, by the other end at the peoples eares, who stood a farre of that chayne fastned to his tong" (George Puttenham, The Arte of English Poesie). De façon similaire, Arthur captive et subjugue son adversaire adulte grâce à son éloquence, bien que ne possédant ni l'âge, ni la stature d'Hercule. Cette différence majeure rend le triomphe d'Arthur encore plus spectaculaire et renforce sa puissance dramatique. Les discours hautement rhétoriques d'Arthur l'associent-ils immanquablement à la duplicité en compromettant la vraisemblance de son jeune âge ou, au contraire, une stylisation aussi marquée doit-elle être perçue comme un stimulus esthétique qui se suffirait à lui seul, libéré des contingences narratives et du souci de vraisemblance ? Après avoir analysé l'appareil rhétorique de la pièce, mon article tentera de démontrer qu'il est possible de considérer Arthur comme un enfant faisant usage de la rhétorique et de la duplicité pour faire face aux intentions des adultes.

$\mathrm{I}$

n Act IV, scene i of The Life and Death of King John (1596), John's nephew and political rival Arthur frustrates the attempt to blind him solely with copious and rather mannered protestations of his helplessness. ${ }^{1}$ Tired of the boy's verbal resistance, his adult adversary Hubert reprimands him at one point in the scene: "Is this your promise [of keeping quiet]? Go to, hold your tongue!” (Iv.i.96) ${ }^{2}$ Arthur,

\footnotetext{
1 The historical Arthur Plantagenet, Duke of Brittany (1187-1203) was actually in his early teens when he was captured by the English in 1202. In a related play, the anonymous Troublesome Raigne of John, King of England (1591), Arthur is an older and much more confident youth who is adamant about his political rights and participates as a soldier and fights in the battle scenes. Louis, the French king's son, was the same age as Arthur, but both plays show him as a mature, warlike young man.

2 All references to Shakespeare's plays in this article are keyed to The Norton Shakespeare: Based on the Oxford Edition, Stephen Greenblatt, Walter Cohen, Jean E. Howard, and Katharine Eisaman Maus, eds., New York, W. W. Norton, 1997. All citations for Shakespeare's plays are in the body of the essay.
} 
unabashed, justifies his loquacity by comparing the merits of the eyes and the tongue, and turns Hubert's request on its head: "Hubert, the utterance of a brace of tongues / Must needs want pleading for a pair of eyes / Let me not hold my tongue, let me not, Hubert." (Iv.i.97-99). Immediately after that, he capitalizes on the phrasing of the rebuke to change his request and thus buy time. He prays that his eyes be preserved and his tongue be cut instead: "Or, Hubert, if you will, cut out my tongue, / So I may keep mine eyes: / O, spare mine eyes." (Iv.i.99101). It is Arthur's superlative articulacy and persuasiveness, suggested by his own hyperbolical image of "a brace [or a pair] of tongues", that protects his eyes as well as his tongue. According to the dominant reading of the scene, Arthur's "innocent prate" saves the day for him. ${ }^{3}$ But it shall be my contention that Arthur, who has to his credit the largest number of lines by a child character in a single scene of a Shakespeare play and the second-largest number of lines by any child character in the entire Shakespeare corpus, deploys his tongue in a conscious and well-orchestrated way that need not square with the cultural stereotype of childlike innocence.

Arthur's linguistic exploits may be seen as a nod in the direction of the popular adage Eloquentia fortitudine praestantior, or "eloquence is superior to physical might”. In Andrea Alciato's Emblematum Liber of 1531, which had more than a hundred editions in several European languages by the 1620 s, the motto is attached to a woodcut of Hercules Gallicus - Hercules captivating a multitude of people not by his physical strength but by his tongue. The connection between Hercules Gallicus and the boy Duke of Brittany in Shakespeare's play is not an obvious one, but the stage spectacle of the child manipulating a hostile adult with the help of his tongue makes for a variation on the original motif that is conducive to theatrical surprise and thrill. The incongruity and reversal of expectations characterizing this tableau further inspire questions about the cultural formulation of rhetoric and how it inflects the construction of childhood. Before weighing these issues, a more detailed look at the scene is in order.

At the beginning of the scene, even before he comes to learn about King John's order, Arthur starts harping on his abject condition and tries several strategies in quick succession in order to elicit sympathy from Hubert. He is discerning enough to sense that Hubert is

3 Adrian Poole, Shakespeare and the Victorians, London, Thomson, 2004, p. 51. 
"sad" (IV.i.11) and makes use of this discovery to launch into a bout of self-pity. In the same breath, he emphasizes the authenticity of his sorrow by contrasting it with the affected melancholy of the prototypical innamorato: "Yet, I remember, when I was in France, / Young gentlemen would be as sad as night / Only for wantonness" (IV.i.14-16). Arthur homes in on the ground reality of his internment with startling perspicacity. Hubert is obviously shaken by what he calls in an aside Arthur's "innocent prate" (Iv.i.25), and resolves to "be sudden, and despatch" (IV.i.27). The boy further aggravates his discomfiture by an emphatic display of solicitude:

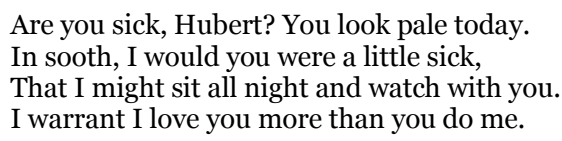

(IV.i.28-31)

Arthur's loving care for Hubert seems to be selfless, if a bit stilted and self-conscious, at this point. It makes for heady dramatic irony, for the audience has already seen the executioners who are now waiting in the wings. However, soon after Hubert shows him John's written order for blinding Arthur, the boy recounts past services he voluntarily rendered to Hubert and demands adequate reciprocity (IV.1.41-52). Oddly enough, few lines earlier Arthur was eager to renounce his princely lineage and station in favour of the simpler and freer life of a shepherd. Now he emphasizes his pedigree to show that he had disregarded feudal hierarchy and stooped below his rank for tending to the lowly Hubert at the hour of his illness. What is more fascinating, Arthur himself anticipates the probable accusations of hypocrisy and astuteness against himself. He fluently spells out the charges in the process of pleading with Hubert, and even dares him to act on them:

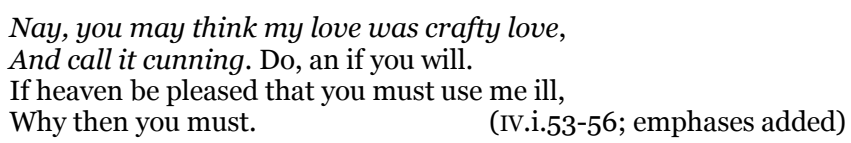

It is quite clear that Arthur does not take the option of dignity and fortitude in the teeth of adversity that would be more in keeping with the mien of a future warrior and prospective king. Instead, he invents one excuse after another to weaken Hubert's determination and defer the blinding. 
To begin with, when Hubert ignores his challenge and reiterates his determination to carry out the order, Arthur concocts an elaborate and fantastic description of the iron poker as a sentient and moral being that takes pity on him. The image obliquely but scathingly emphasizes Hubert's cruelty:

The iron of itself, though heat red-hot,

Approaching near these eyes, would drink my tears,

And quench his fiery indignation

Even in the matter of mine innocence;

Nay, after that, consume away in rust

But for containing fire to harm mine eye.

Are you more stubborn-hard than hammered iron?

(IV.i.61-67)

Unmoved, when Hubert signals the executioners to reveal themselves and do his bidding, Arthur cries out in sheer terror, "O, save me, Hubert, save me! my eyes are out / Even with the fierce looks of these bloody men" (IV.i.72-73). As Hubert takes the iron in his own hands, Arthur requests him to send away the executioners and promises to stay silent and calm. This move is guided by the intelligent conjecture that Hubert would not be as ruthless as a hardened, professional slaughterer. But as one of the executioners adds as a parting shot that he is "best pleased to be from such a deed" (IV.i.85), Arthur discovers a sympathetic soul in him and promptly reverses his request:

Alas, I then have chid away my friend!

[...] Let him come back, that his compassion may

Give life to yours. (IV.i.86-89; emphases added)

Arthur then seeks to stimulate his adult adversary's empathy, challenging him to imagine:

O heaven, that there were but a mote in yours [i.e., eyes],

A grain, a dust, a gnat, a wandering hair,

Any annoyance in that precious sense,

Then feeling what small things are boisterous there,

Your vile intent must needs seem horrible.

(IV.i.91-95)

When this strategy fails, Arthur offers his tongue in lieu of his eyes. Rebuffed by Hubert, he goes on to describe the iron poker as a sympathetic being that is more ethically predisposed than his human custodian - a comparison he had initiated earlier. 


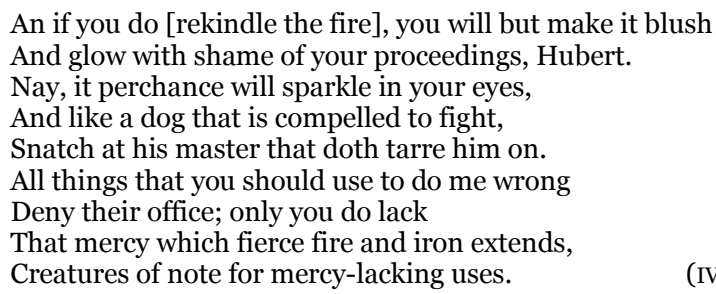

Of all the ruses and strategies that Arthur adopts to avoid being blinded, the invocation of the anthropomorphic iron seems to be the most embarrassingly contrived. Curiously, while all other tactics fail, the persistent contrasting of Hubert with the scandalized, sympathetic iron finally manages to dissuade him from injuring Arthur. The boy greets his decision with a pithy but sententious rhetorical flourish unlike a child: "O, now you look like Hubert! All this while / You were disguised' (Iv.i.125-126). However, it becomes clear from Act IV, scene i, that Arthur does not trust Hubert at all, notwithstanding the latter's unconditional promise to protect him from King John. That is why the insecure and frustrated Arthur in a desperate bid to escape jumps from the prison walls and kills himself. In retrospect, he may be found speaking just as Volumnia advised Coriolanus to, "with such words that are but rooted in / Your tongue, though but bastards and syllables / Of no allowance to your bosom's truth" (III.ii.55-57).

In his Theophrastean sketch on the child in Microcosmography (first published 1628), John Earle observes, "His [the child's] hardest labour is his tongue, as if he were loath to use so deceitful an organ; and he is best company with it when he can but prattle". ${ }^{4}$ Earle pictures the child as a totally guileless creature who uses the tongue only for frivolous and purposeless inanities. As against this, Arthur's deployment of his tongue is thoroughly astute and it also admits of deceit. Arthur's cleverness as seen above cannot be conveniently explained away by invoking Philippe Ariès's famous thesis that children in the West were regarded as miniature and deficient adults well into the sixteenth century, because this claim itself has been stiffly and cogently opposed by later historians. 5 However, the disjunction between Earle's model of

\footnotetext{
4 John Earle, Microcosmography, or Pieces of the World Discovered in Essays and Characters, London, White and Cochrane, 1811, p. 2.

5 Philippe Ariès, Centuries of Childhood: A Social History of Family Life, trans. Robert Baldick, New York, Vintage Books, 1962, especially p. 33-49. For the contesting view, see
} 
the child and Arthur's embodied performance as a child bears out the coexistence of multiple discourses about childhood within the same culture.

It is not justified to club Arthur indiscriminately with other child characters of the Shakespeare canon and justify their garrulity in terms of overarching historical or aesthetic parameters. Marjorie Garber does just that as she returns a sweepingly dismissive verdict on Shakespeare's children. In her opinion,

Those [child characters] who do appear [in the plays of the Shakespeare canon] are both pert and malapert, disconcertingly solemn and prematurely adult: the Princes in the tower, whose uncle's exasperation with them may be shared to a degree by the audience; Macduff's and Coriolanus' sons, both pathetically martial copies of their fathers; Mamillius, whose proposal to tell a 'sad tale ... for winter' reveals an intuitive comprehension of the problems of Sicilia and of his own impending doom. These are not, by and large, successful dramatic characters; their disquieting adulthood strikes the audience with its oddness, and we are relieved when these terrible infants leave the stage. We may feel it to be no accident that almost all go to their deaths. ${ }^{6}$

Pace Garber, Shakespeare's plays do not treat precocity in children as a monolithic and predictable given, and his precocious child characters are in fact amply individuated. For example, Arthur is obviously more perceptive and foresighted than Prince Edward of Richard III who for all his schoolboy wisdom about Julius Caesar is unable to figure out the danger awaiting him in the Tower of London. Similarly, Arthur is not shallow like the boy York of Richard III or Macduff Junior who can attempt impish wisecracks totally unaware of the looming political menace.

Keith Wrightson, English Society, 1580-1680, New Brunswick, NJ, Rutgers University Press, 1982; Linda A. Pollock, Forgotten Children: Parent-Child Relations from 1500 to 1900 , CUP 1984. As Karin Calvert observes, "Ariès bases many of his assumptions about medieval society on a lack of discernible distinctions between adult and children". She goes on to argue rather strikingly that, "Unfortunately, the lack of manifest distinctions in any particular area is not evidence of a lack of recognized distinctions between different social groups. [...] This should be very evident to a society in which members of both sexes, and persons of all ages and social classes, wear blue jeans and sneakers [...]." Karin Calvert, Children in the House: The Material Culture of Early Childhood, Boston, Northeastern University Press, 1992, p. 10-11. See also Kate Chedgzoy, "Playing with Cupid: Gender, Sexuality, and Adolescence", in Diana E. Henderson, ed, Alternative Shakespeares, vol. 3, London, Routledge, 2008 , p. 138-157 (p. 156). In all fairness to Ariès, his argument is more sophisticated than is made out by his detractors, and he does acknowledge the possibility of a hiatus between an experience and the cultural representation of it.

6 Marjorie Garber, Coming of Age in Shakespeare, New York, Routledge, 1997, p. 30. 
It also needs to be stressed that Arthur is not an anagogic vehicle of divine agency as celebrated in Psalm 8:2: "Out of the mouth of babes and sucklings hast thou ordained strength because of thine enemies, that thou mightest still the enemy and the avenger." Further, the play does not identify him as a puer senex or boy sage, the archetype for which is furnished by the boy Christ himself as he debates with the doctors of the Temple in Luke 2:46-47. On the other hand, Arthur's speeches do not contextually form a pedagogic or professional exercise that would be in keeping with the humanist training of an early modern schoolboy. ${ }^{7}$ If presented in the correct manner and time, a prolix and flamboyant speech would not earn a schoolboy the censure for garrulity or precocity, but might win him appreciation for his learned skills. This might be illustrated by an episode from Gargantua (published in French in 1534), where a twelve-year old page delivers an elaborate epideictic address before guests at the bidding of his tutor:

Then Eudemon [the page], asking leave of the vice-king his master so to do, with his cap in his hand, a clear and open countenance, beautiful and ruddy lips, his eyes steady, and his looks fixed upon Gargantua with a youthful modesty, standing up straight on his feet, began very gracefully to commend him; first, for his virtue and good manners; secondly, for his knowledge, thirdly, for his nobility; fourthly, for his bodily accomplishments; and, in the fifth place, most sweetly exhorted him to reverence his father with all due observancy, who was so careful to have him well brought up. In the end he prayed him, that he would vouchsafe to admit of him amongst the least of his servants; for other favour at that time desired he none of heaven, but that he might do him some grateful and acceptable service. All this was by him delivered with such proper gestures, such distinct pronunciation, so pleasant a delivery, in such exquisite fine terms, and so good Latin, that he seemed rather a Gracchus, a Cicero, an Aemilius of the time past, than a youth of this age. ${ }^{8}$

\footnotetext{
7 Although Arthur's speeches in this scene are laden with signs of a rhetorical training, they cannot be matched accurately to the template of any formal and regimented rhetorical composition. For the various kinds of exercises and compositions that a schoolboy had to go through under the humanist pedagogy, see Peter Mack, Elizabethan Rhetoric: Theory and Practice, CUP, 2002, p. 1-47. An early modern schoolboy was saturated with rhetoric, but he would hardly be counted on to save his life by displaying his rhetorical skills. However, this is exactly what happens in the scene under review, and this is how the scene exceeds the pragmatic or quotidian expectations.

8 François Rabelais, Gargantua, Five Books of the Lives and Deeds of Gargantua and His Son Pantagruel, trans. Thomas Urquhart and Peter Antony M otteux, Derby, Moray Press, 1894, Book 1, translated by Thomas Urquhart in 1653, Chapter 1.XV.

http://en.wikisource.org/wiki/Gargantua/Chapter XV (accessed 17 March, 2012).
} 
As opposed to this, Arthur hardly enjoys the opportunity for a wellrehearsed and full-fledged ceremonial declamation. Needless to say, the contextual incongruity of Arthur's bravura performance enhances its surprise value for latter-day readers.

E.M.W. Tillyard has pointed out Arthur's pleading to be a discrete rhetorical set-piece whose focus is exclusively aesthetic:

In itself the business over Arthur's body [in Act IV, scene iii] is superb, but its energy and its freedom of style are quite alien to Arthur pleading with Hubert for his sight. This pleading is usually praised as very pathetic or condemned as intolerably affected. It is indeed affected, but to an Elizabethan audience would not have been intolerable. They probably enjoyed it as an exhibition of rhetoric; and as such it is finely built up, an elegant exercise into word-play, like many other scenes in Shakespeare. It does not, however, square very well with the more vigorous excesses of language [as exemplified by Philip the Bastard] [...] in fact it does not fit naturally into the play at all. 9

The rhetorical préciosité of Arthur's speeches becomes clear when we juxtapose them with those of Shakespeare's other child who pleads for his life, the boy Earl of Rutland in 3 Henry VI (I.iii.13-21, 41-46). Arthur's eloquence of course would not appear so primal and hardhitting to the modern audience as Young Coriolanus' " $A$ ' shall not tread on me; / I'll run away till I am bigger, but then I'll fight” (v.iii.128-129), or even Mamillius' traumatized silence as he is plucked away from his slandered mother. But it is possible to argue that Arthur's performance admits of sufficient realism insofar as it seeks to extend the characterization of the child beyond the more widely accepted cultural paradigms of pristine innocence or frolicsome garrulity (as suggested by Earle's sketch) or even of preternatural wisdom (as in the tradition of the puer senex). ${ }^{10}$

9 E.M.W. Tillyard, Shakespeare's History Plays, 1944, Harmondsworth, Penguin, 1969, p. 238 .

10 According to Michael Witmore, "a body of popular intuitions about children and childhood" operative since the Middle Ages agreed that "children were without guile, were captive to their immediate appetites, were sexually naive, or were the epitome of improvidence". Since the actions of the children were believed to issue from the organic soul rather than the intellective one, children had become "an exemplary figure for all that humans lack when they are stripped of reason and experience". Michael Witmore, Pretty Creatures: Children and Fiction in the English Renaissance, Ithaca, Cornell University Press, p. 15. In keeping with this discourse, the (occasional) wisdom shown by children would be considered as a specially ordained exception to the rule, and traced to an agency beyond the rational capacity of the children. 
In her essay "Shakespeare's Little Boys", Catherine Belsey has regarded this scene as thickly stylized, and operating away from the strictures of illusionistic representation. "While the blinding scene is unequivocally theatrical," she observes, "its dramatic mode is emphatically not mimetic. Arthur does not talk quite as we should expect of a frightened child."11 Using Robert Weimann's differentiation between "presentation" and "impersonation," she points out,

'presentation' specifies an emotion or a state of mind, points to it, defines it, as if from outside; on the other hand, 'impersonation' enacts it mimetically. Weimann attributes presentation to an earlier form of drama, before the author took control of the stage with a view to creating an illusion of a self-contained fictional world. In this sense, Prince Arthur 'presents' his own pathos to Hubert and to the audience in a succession of conceits that we should not expect a modern child to utter. ${ }^{12}$

This line of argument is quite insightful, but Belsey does not explain why 'presentation' and 'impersonation' should be taken as chronologically distinct and mutually exclusive modes of representation. If we see these modes as concurrent and present simultaneously in different layers of performance, the reading can be more nuanced. Weimann himself had earlier envisaged the early modern English stage as a fraught site of interaction between disparate paradigms and tropes of performance:

It is in this larger context of a transitional age that the popular theater, with its ritual heritage and its enchanting and disenchanting modes of mimesis, could make so powerful an impact on the nation's drama and enhance the tension as well as the unity between "naturalism" and "convention." The two modes, far from being mutually exclusive, helped to constitute the universalizing pattern in Shakespeare. ${ }^{13}$

Belsey seems to suggest that the message conveyed by Arthur's performance is that of his innocence, while the medium chosen for it is unmistakably eloquence. At least on the primary and material level of

11 Catherine Belsey, "Shakespeare's Little Boys: Theatrical Apprenticeship and the Construction of Childhood", in Bryan Reynolds and William N. West, eds., Rematerializing Shakespeare: Authority and Representation on the Early Modern English Stage, New York, Palgrave Macmillan, 2005, p. 53-72 (p. 61).

12 Ibid. See also Robert Weimann, Author's Pen and Actor's Voice: Playing and Writing in Shakespeare's Theatre, Cambridge, C.U.P., 2000.

13 Robert Weimann, Shakespeare and the Popular Tradition in the Theater: Studies in the Social Dimension of Dramatic Form and Function, ed. Robert Schwartz, Baltimore and New York, Johns Hopkins University Press, 1978, p. 251. 
the theatrical apparatus, she would accept the scene as enacting the triumph of Arthur's tongue. One has to therefore negotiate and analyze the signifier of eloquence, in which the play is so ardently invested, before one can impute innocence or otherwise as a signified to him. Here lies the relevance of the tableau of Hercules Gallicus.

A part of the problem with Arthur lies in relating him as a child to the deceitfulness associated with rhetoric, and its anatomical metonym, the tongue. Whereas rhetoric formed an indispensable part of the early modern curricula, there was also a distinguished tradition of suspicion towards it. Even if we disregard Plato's attack on rhetoric in Gorgias and Phaedrus, the rhetoricians themselves are often painfully aware that their art has great power to puzzle and mislead. Erasmus of Rotterdam, the greatest humanist scholar, himself condemned the tongue in his Lingua, based on Plutarch's treatise De Garrulitate. Side by side with the proliferation of rhetorical handbooks and style guides there was a constituency for encyclopedic and homiletic works on the tongue such as Jean de Marconville's A Treatise of the Good and Evell Tongue (translated into English around 1592), George Webbe's The Arraingnement of an Unruly Tongue (1619), Thomas Adams's The Taming of the Tongue (1619), John Abernethy's The Poysonous Tongue (1622), William Gearing's A Bridle for the Tongue (1663), and Richard Allestree's The Government of the Tongue (1674). These works would often use as their launch pad the renunciation of the tongue in James 3:3-8, which makes much of the small organ's incommensurately huge power to rebel, delude and corrupt:

When we put bits into the mouths of horses to make them obey us, we can turn the whole animal. Or take ships as an example. Although they are so large and are driven by strong winds, they are steered by a very small rudder wherever the pilot wants to go. Likewise, the tongue is a small part of the body, but it makes great boasts. Consider what a great forest is set on fire by a small spark. The tongue also is a fire, a world of evil among the parts of the body. It corrupts the whole body, sets the whole course of one's life on fire, and is itself set on fire by hell. All kinds of animals, birds, reptiles and sea creatures are being tamed and have been tamed by mankind, but no human being can tame the tongue. It is a restless evil, full of deadly poison.

The theme of demonization and renunciation of the tongue also lent itself to much iconographic representation during the early modern period. Three of them have been discussed by Carla Mazzio in her 
landmark essay. ${ }^{14}$ Taken chronologically, the first is an engraving by Nicoletto de Modena (c. 1507) entitled Le sort de la langue méchante and containing the motto, Lingua pravorum peribit ("The perverse tongue shall be cut off'). The second is an emblem occurring in Georgette de Montenay's anthology Emblemes ou devises chrestiennes (1571) and tagged as Frustra me colunt ("In vain do they worship me"). It shows Hypocrisy in the figure of a nun stretching her hands to keep farthest apart the two organs held in them, the tongue (standing for articulation) and the heart (standing for true and sincere emotion). The third is the emblem of the flying tongue that appears in George Wither's A Collection of Emblems Ancient and Modern (1635). The same emblem is to be found in Claude Paradin's Devises Heroiques (1551) and Gabriel Rollenhagen's Nucleus emblematum (1611). It is remarkable that detractors of rhetoric are united with its champions in granting the tongue a tremendous amount of power, that of swaying the listener. Shakespeare's Julius Caesar amply substantiates that he was alert to the affective capacity of rhetoric, to its intrinsic link with sophistry and demagoguery - so much so that he was in a position to dramatize and ironize these tendencies. Arthur for one seems to take in a pragmatic and material sense the maxim of Proverbs 18:21: "Death and life are in the power of the tongue: and they that love it shall eat the fruit thereof."

A famous pictorial representation of the spell-binding power of the tongue has been described by George Puttenham in The Arte of English Poesie (1589):

I find this opinion [about the seductive force of rhetoric], confirmed by a pretie devise or embleme that Lucianus alleageth he saw in the pourtrait of Hercules within the citie of Marseills [Marseille] in Provence: where they had figured a lustie old man with a long chayne tyed by one end at his tongue, by the other end at the peoples eares, who stood a farre of that chayne fastned to his tongue, ass who would say, by force of his perswasions. $^{15}$

As Puttenham correctly points out, the emblem has been described by the second century satirist Lucian of Samosata. In his short tract in Greek entitled Heracles: An Introduction, Lucian attempts a vibrant

\footnotetext{
14 Carla Mazzio, "Sins of the Tongue", in David Hillman and Carla Mazzio, eds., The Body in Parts: Fantasies of Corporeality in Early Modern Europe, New York and London, Routledge, 1997, p. 53-79 (p. 54, 60, 62).

15 George Puttenham, The Arte of English Poesie, Gladys Doidge Wilcock and Alice Walker, eds., Cambridge, CUP, 1936, p. 154.
} 
ekphrasis of a portrait of Hercules that he putatively came across during his sojourn in the land of the Celts:

That old Heracles of theirs drags after him a great crowd of men who are all tethered by the ears! His leashes are delicate chains fashioned of gold and amber, resembling the prettiest of necklaces. Yet, though led by bonds so weak, the men do not think of escaping, as they easily could, and they do not pull back at all or brace their feet and lean in the opposite direction to that in which he is leading them. In fact, they follow cheerfully and joyously, applauding their leader and all pressing him close and keeping the leashes slack in their desire to overtake him; apparently they would be offended if they were let loose! But let me tell you without delay what seemed to me the strangest thing of all. Since the painter had no place to which he could attach the ends of the chains, as the god's right hand already held the club and his left the bow, he pierced the tip of his tongue and represented him drawing the men by that means! Moreover, he has his face turned toward his captives, and is smiling. ${ }^{16}$

As Lucian looks befuddled at the portrait, a friendly Celt comes to his rescue and deciphers the emblem for him in this fashion:

We Celts do not agree with you Greeks in thinking that Hermes is Eloquence: we identify Heracles with it, because he is far more powerful than Hermes. And don't be surprised that he is represented as an old man, for eloquence and eloquence alone is wont to show its full vigour in old age.... This being so, if old Heracles here drags men after him who are tethered by the ears to his tongue, don't be surprised at that, either: you know the kinship between ears and tongue.... In general, we consider that the real Heracles was a wise man who achieved everything by eloquence and applied persuasion as his principal force. ${ }^{17}$

As has already been mentioned, it was a popular theme in the emblem literature of the period. For example, seven different engraved compositions of the emblem can be located in seven editions of Andrea Alciato's work: Emblematum liber (Augsburg, 1531), Emblematum libellous (Paris, 1534), Los Emblemas (Lyon, 1549; Spanish translation), Emblematum libri II (Lyon, 1556, with commentary by Sebastian Stockhamer), Liber emblematum [...] Kunstbuch (Frankfurt on Main, 1567, German translation by Jeremias Held), Emblemata (Leiden, 1591), Emblemata (Padua, 1621). Given the wide pictorial circulation of the motif, its familiarity in England is more than a fair possibility. More

\footnotetext{
16 Lucian, "Heracles: An Introduction”, in Lucian, trans. A.M. Harmon, 8 vols, Loeb Classical Library, Cambridge, MA, Harvard University Press, 1913, vol. 1, p. 61-71 (p. 65).

17 Ibid., p. 65, 67.
} 
importantly, it enjoyed some amount of currency in England thanks to the tradition of humanist learning. Four decades before Puttenham, Thomas Wilson had mentioned the same emblem in The Art of Rhetoric (1553), with the difference from Puttenham that he more strongly required wisdom or reason to be the immediate source and correlate of eloquence:

[T] he poets do feign that Hercules, being a man of great wisdom, had all men linked together by the ears in a chain, to draw them and lead them even as he lusted. For his wit was so great, his tongue so eloquent, and his experience such, that no one man was able to withstand his reason, but everyone was rather driven to do that which he would and to will that which he did, agreeing to his advice both in word and work in all that ever they were able. ${ }^{18}$

Arthur's true peer in terms of garrulity is the page named Mote (or Moth) appearing in Love's Labour's Lost, who in fact has the largest number of lines for any child character in the Shakespeare canon. Incidentally, he plays the infant Hercules in the pageant of the Nine Worthies authored by Holofernes (Act v, scene ii). He is not allowed a single word because of the infancy he portrays - etymologically related to the inability to speak. Thus Mote physically and functionally is made to invert the image of Hercules Gallicus. On the other hand, Arthur introduces a variation on Hercules Gallicus only physically, not functionally. He can captivate and sway an adult with his eloquence, although he does not have the stalwart physical presence of a Hercules. Arthur is not shown as having "wit" (i.e., knowledge) and "experience", which are claimed by Thomas Wilson to be essential attributes of the elderly Hercules. Puttenham makes the divergence more obvious as he expatiates upon the emblem:

And to shew more plainly that eloquence is of great force (and not as many men think amisse) the propertie and gift of yong men onely, but rather of old men, and a thing which better becommeth hory haires then beardlesse boyes, they seeme to ground it upon this reason: age (say they and most truly) brings experience, experience bringeth wisedome, long

18 Thomas Wilson, The Art of Rhetoric, in Wayne A. Rebhorn, ed., Renaissance Debates on Rhetoric, Ithaca, NY, Cornell University Press, 2000, p. 174-82 (p. 176). It is noteworthy that Wilson, like Lucian, associates Hercules' eloquence with honest and constructive leadership and ignores the potential of manipulative demagoguery. Wilson might have been influenced by the legend of "the choice of Hercules", where the upright hero opted for Virtue over Pleasure. For a treatment of the theme in early modern England, see Jonson's masque, Pleasure Reconciled to Virtue (1608), in David Lindley, ed., Court Masques: Jacobean and Caroline Entertainments, 1605-1640, Oxford and New York, OUP, 1995, p. 117-125. 
life yeldes long use and much exercise of speach, exercise and custome with wisedome, make an assured and volluble utterance: so is it that old men more then any other sort speake most gravely, wisely, assuredly, and plausibly, which partes are all that can be required in perfite eloquence $[\ldots]^{19}$

That Arthur, lacking "hoary haires" and being a "beardless" boy, can verbally manipulate the adult Hubert's affections is a source of wonder, and this generates a thrilling spectacle on the stage. Arthur lacks Hercules' muscle-bound physique, but he makes a masterful use of the particular muscle that, as Carla Mazzio points out, "was able to move beyond the bounds of immediate material circumstances, to literally affect lives from a distance," and that in early modern literature and iconography "was imagined as the ultimate locus of exteriority, as the site where the self was performed, replicated." 20 The question again arises, if the eloquence of Hercules Gallicus is enabled and sustained solely by the knowledge and experience of his advanced years, how do we explain the child Arthur's dazzling articulacy? Notably, Lucian's emblem happily acknowledges the materiality of Hercules' rhetoric by allegorizing it as "leashes" that "are delicate chains fashioned of gold and amber, resembling the prettiest of necklaces." ${ }^{21}$ It would be wrong to obliterate the manipulativeness of Arthur's eloquence and treat it as a transparent and unproblematic theatrical medium for the 'presentation' of his innocence.

One is likely to pass over these nuances if one works from a premeditated notion of childhood and childlike-ness. This tends to place Arthur in a no-win situation: if he has to operate as a child character on the stage he must establish his innocence and helplessness, in order to do so he must speak out, but if he speaks successfully in the stage idiom he is not a child. One way of transfixing Arthur in a state of unqualified innocence is to selectively read his adroit verbal manoeuvres as guileless outpourings and not as survival strategies. In conjunction with this, one may refuse to associate Arthur's pleas with any coherent and longstanding construction of interiority that would be valid beyond the scene. This is the path taken by Hubert and other adult characters in the play, and ostensibly sponsored by the playwright. Another way to save

\footnotetext{
19 Puttenham, op. cit., p. 142. Emphases added.

${ }^{20}$ Mazzio, op. cit., p. 57, 63

${ }^{21}$ Lucian, op. cit., p. 65
} 
him from the accusation of adult-like slyness and the taint of dubious rhetoric is to stress that his eloquence is a one-dimensional and formulaic device that is not inflected by the dramatic context. This is the path taken by most critics. It may be more worthwhile, this study has tried to suggest, to recognize that the character of Arthur makes sense as a child beleaguered by a hostile adult world and trying desperately to cope with it. Arthur cannot afford to smile indulgently at the captive of his eloquence and lead him in a leisurely fashion as Hercules Gallicus does. In the unenviable situation where Arthur finds himself, his tongue is the only weapon he is left with and he makes use of it for the sake of survival.

Abishek SARKAR

Calcutta 